\section{THE WAR IN TURKEY.}

THe following extract from a letter written by an English Medical Officer, who has been serving in one of the hospitals in Bosnia, will prove interesting to our readers:-

"The hospital is now filled with scurvy, dysentery, ague, and diarrhoos. The number suffering from scurvy that present themselves daily in the out patient ronm is quite appalling. We are quite close to the Servian and M.ratene. grin frontier, and within two days' journey of Herz govina. Two days ago the Montenegrins came unpleasantly close here and burnt a village, killing all the inhahitants. The Turks pursued tbem and killed twenty-five Mintenegrins. People in England have no idea bow the Russians are secretly at work among the Survians and Bosnians and elsewhere, inciring them to rebellion, and everyone knows that the peace negotiations with Montenegro, prolonged from week to week as they were, and which fell through after. wards, were the result of Russian intrigue to gain time. They never meant to make peace. We have here now only a few compunies of the regulars and one battalion of Albanian Bashi. Baz ruks, and most ferocious-looking fellows they are too. I believe, for ferocity, they are on a par with the Montenegrins, and that is saying a gord deal. There is not a pin to choose between the Bashi-Bazouks and the Christian peasantry. One sect is quite as cruel as the other. They are all half savages. I have been living for nearly nine months amongst a horde of savages; still, on the whole, I don't regret the experience. F.r. the last two montbs I have not heard a word of the Englis' language spoken-nothing but Turkish, French, Bosniac, Arnaut, Armenian, Greek, and Italian. I am quite like an exile, and I cannot tell you bow glad I am to get a way. The Danube will be much more pleasant. If you have any friend coming out to the war, I shall be glad to render him any assistance. It will he a good experience for any young fellow just qualified. We gut paid in money, not in paper: $£ 20$ a month and four rations a day, or its equivalent in money; 225 per passage out, and 225 back after the war is over."

\section{Cortespondence.}

$$
\text { "Audi alteram partem." }
$$

\section{QUEEN CHARLOTTE'S LYING-IN HOSPITAL.}

\section{To the Editor of ThE LANCET.}

Sir,-In The Lancet for January $20^{\circ} \mathrm{h}, 1877$, the statistics of Queen Charlitte's Lying-in Hospital for twenty years, ending 1876 , will be found, showing that 7613 women were delivered in the hospital; of these 220 died, a deathrate of 1 in 35, ranging annually from 1 in 114 to 1 in 12 patients.

I now send you the statistics of the maternity department of St. George's Hospital for nearly the same periodviz., from 1854 to the end of 1876 , during which time 7952 women were delivered at their own homes, with 28 deaths ( 7 of these are said not to have been due to the puerperal state), being one death in 284 deliveries. In the last five years, out of 2377 women delivered the deatbs were four, about 1 in 594. 'These women were all attended by students of the hospital, under the supervision of the obstetric assistant, and, when necessary, the obstetric physician.

In the year 1876, 3069 women were delivered at their own homes by the midwives of the Rinyal Maternity Charity, with six deaths, abrout 1 in 511 (117 required the attendance of the physician). I am indebted for the St. Grorge's Hospital statistics to the paper by Mr Harper, the ohstetric assistant, in the volume of "Hospital Reports" just published, and the others are from the annual report of the Royal Maternity Charity. I think The LANCET would do much service were the records of the other lying-in charities produced in its pages.

Had I wanted any further confirmation of my own opinion-however valueless that may be,-after watching carefully the working of a lying-in hospital for twenty sears, that these hospitals should be closed, I should have f rund it in the reasoning on the causes of puerperal fever, and on its trentment, by Dr. Priestley in his adilurs to the Obstetrical Suciery. I now leave to the practitioners of midwifery the eettling of this question. If lying in hospitals continue the responsibility will rest with them.

I am, Sir, your obedient servant,

Savile-row, June 23rd, 1877.

Charles Hawkins.

P.S - $\mathrm{I}$ miy state in the annual report of $Q$ ueen Coarlotte's Hospitial the number of women delivered in twenty years is stated to be 7513 ; it ought to be 7613 .

\section{POOR-LAW MEDICAL OFFICERS' ASSOCIATION.} To the Editor of The Langet.

Srn,-I trust you will permit me to remind the members of the Poor-lali medical service that the annual meeting of the Association will be held at 3, Bolt-court, Fleet-street, on Tuesday, July 3rd, at 3 P.Mr. precisely, when, besides certain matters of a routine character, subjects of considerable interest to metropolitan as well as provincial members will be discussed, such as the abuse of authority by the police in converting workhouse infirmaries in to continuous police-stations; the extension of the provision by hoards of guardians of expensive medicines; the necessity for the establishment of dispensaries in provincial towns; the consideration of scme important correspondence with the L cal Government Board anent the question of extra fees; the Permissive Superannuation Act, \&c.

The work done by the Council during the last twelve montbs, though not attracting public at tention so markedly as in past years, has nevertheless shown the absolute necessity for such an organisation, seeing that we have been frequently applied to for information, advice, and support, by Poor-law medical officers who, without our assistance, would have been at a loss to know where to turn for help.

The Council therefore trust that members and friends of the Association will strive to put in an appearance, as it is very desirable that no apathy or lack of interest should be exhibited.

I am, Sir, yours obediently,

Dean-street, June 25th, 1877
Joseph Rogers, Chairmau of Council.

\section{THE UNIVERSITY OF LONDON AND MEDICAL WOMEN.}

To the Editor of THE LANCET.

Srn,-In your article on "The University of London and Medical Women" you state that "on a former occasion $\mathrm{Mr}$ Fowler voted in the majority, on Wednesday in the minority." As you have done me the honour to refer to my vote, will you permit me to explain it. When on the previous occasion to which you refer the question was raised, I had not the opportunity of considering the position in which the University was placed. Mr. Goldsmid moved an amendment which seemed to me to prejudge the question of the admission of women to degrees in Arts. Having on all previous divisions opposed this, I $f \in l t$ bound in consistency to continue to do so. The motion of Mr. Osler for their admission to medical degrees was then put, and in that division I took no part. My reason for not viting was that it had been strongly urged by an eminent mediral man present, who himself expressed in eloquent terms his abhorrence of the change, that the Act of last sessenn left us no option but to acquiesce in it. This argnment $I$ wished to have time to consider. In the interval between the two weetings of the Senate I gave the qnestion my anxious consideration, and arrived at the con lnsion that it was elearly my duty to support the views of $\mathrm{Sir}$ W. Jenner. As an elected member of the Senate I felt that I ought to pay great deference to the vote of Convocation, especially as on this question the medical laculty was nearly unanimous. I further believe that the views of that faculty were, in the main, sound. It mav be very true that the acion of Parliament places the University in a $d$ ffil alt position, but this seemed to me to be no reason why we should sanction a measure of pernicious tendency. It may be, and I believe 
it is, very desirable that women should acquire such medical knowledyeas would fit them to make improved nurses, and even to practise in the zenanas of the East, but that was not the preposition we had to discuss. The proposal was to place women on a perfect equality with men as medical practitioners. The evils of this proposal have often been ably pointed out by members of the profession; but, speaking as an outsider, I venture to trouble you with the reasons which weigh with me. The evil effects of the change will not be witnessed in the present generation, but I fear the next will bave occasion to rue the innovation which we are now inaugurating. I fear the idea will grow up among ladies, particularly among young ladies, that there is something indelicate in their consulting a gentleman; and should such an idea arise, it will be full of misery to the comfort of families. It will be a most serious evil if, when a young lady is asked by her parents and friends to crnsult some eminent pbysician, she takes it into her head that some lady doctor will do equally well. I know the trial of having relatives who have preferred to consult bormonpathists and bydropathists, and whom I have lost, with the feeling that they had not received proper treatment. I fear these " medical women" will entail a similar trial on many in the next generation.

Apologising for troubling you, I am, Sir, yours obedient]

Carlton Club, Jane 25th, 1877. R. N. Fowler.

\section{THE COUNCIL ELECTION, COLLEGE OF SURGEONS.}

To the Editor of THE LANCET.

Sir,-The approaching election of members of Council is exciting unwonted interest. Considerations of custom and precedent are cast to the winds, and a keen contest is waged with all the arts and energy of a struggle between rival candidates d la mode. How are bewildered fellows to escape the toils of wit, wine, and womanly graces? Dinners, balls, routs, and the captivating eloquence of ladies surprisingly well informed on matters of Cullege interests and policy, are novel argnments withil too potent to be effectually resisted. For myself, Mr. Editor, I have thrown over the idea of be. stowiug my vote, $n$ the brst men; a sober selection is impracticable I have been canvassed personally and by letter, button-boled and curtain-lectured, dined and dazed in the giddy dance, uatil not the least notion remains to me as to the functions of Councillors, or whether the work they are supposed to have in band is pure self-glorification, or something for the public good. Excuse my too apparent ob. fuscation; an election of the class now in progress has been too much for $m p$. I tried to steady myself by reading the President's report. It took me fully three minutes, but despite the singular conciseness with which questions of grave professional interest are discussed in that interesting and important brochure, I am no better able to form a reasonable judgment. Hitherto I have supposed that the Council of the College represented the Fellows and busied itself with their interests, with now and again a thought for the Members, that the grave concerns of surgical science were included in the area of consideration, and that even professional topics of public moment formed suljects of deliberation. I have awakened from that prosaic dream, and my eyes are nearly opened to the discovery that the Council is a sort of Valbulla, to which gentlemen of a certain age and dignity may aspire, and where, in elegant ease, they pass the bappy hours away, innocuous and inert. Verily the method of the contest befirs the future of the successful. I shall vote for the most agreeable and friendly of the rompetitors.-Your obedient servant, June $27 \mathrm{ih}, 1877$.

\section{A Feliow.}

\section{PRESCRIBING AND DISPENSING.}

\section{To the Editor of Tre LaNCET.}

SrR,- The respective merits of prescribing and dispensing, considered in your leading article on the 16 th inst., have often been forced upon me. I formerly dispers.d, and notwithstanding the disadvantages of doing so, I could at least have the satisfaction of knowing that drugs came from a first rate manufacturer. Since I discontinued dispensing I am again and again an noyed by the complaints and doubts of patients in regard to the drugs supplied to them. Making a fair deduction for grumblers, there is sufficient evidence that prescriptions are not always accurately dispensed.

Surely some control over this state of things can be instituted. The purchasers of such commoditirs as fond have themselves a fair experience, in accordance with which they can check the vendor, besides the eafeguards afforded by law. Happily many druggists are conscientious and wellintentioned; where it is otherwise, there must of ten arise powerful temptations to unfaithful dispensing, against the effects of which patients and practitioners are sadly un. protected. Cannot a commission be instituted for privately analysing drugs supplied, and publishing the results? For my own part, I would gladly suhscribe to the expense.

$$
\text { Yours obediently, }
$$

June, 1877. W. WILBERForCE SMITH,

P.S. -The possible variations in the qualities of drugs are well indicated by the "market reports," which show the immense differences in the wholesale prices of the same drug.

\section{THE ACTION AGAINST MR. BATTESON.}

\section{To the Editor of THE LANCET.}

SIR, - My attention has been directed to a letter in your issue of the 23rd inst., written by Dr. Braxton Hicks, under the above heading.

I was present in court when Dr. Braxton Hicks gave his evidence in favour of the defendant in the above cause, and therefore $I$ am in a position to assert, in reference to the last paragraph of his letter, that what he stated was that in the vast majority of face presentations there was no need to interfere, if my ears as well as the ears of the learned coun. sel for the plaintiff did not deceive us. I do not say that Dr. Hicks may not have intended to state that in face presentations there was need to in terf $\mathrm{re}$, but he is mistaken in stating that he made use of that expression at the court. The importance of his answer to the issue which was raised is apparent, and Dr. Braxton Hicks's evidence on this and other points in the case, and his demeanour while under cross-examination by the plaintuff's couveel, bave been a source of some bewilderment to such of his professional brethren as heard him, ever since.

It is impossible for Dr. Hicks to state on any sort of authority that the objection to the employment of unqualified assistants was at the bottom of the trial, and I must take exception to his assuming something wilhont any evidence in support of his bypotbesis for the purpo-e of raising a discussion in your journal on the conduct of the East London Medical Defence Association.

The action raised the simple issue of negligence or no negligence on the part of the $d_{1} f_{e}$ dant Battesun.

As Dr. Hicks has thought it necessary to allude to a matter without his province in referring to the circumstances under which the action was hrought, I may state that I was retained by the husband of the deceased woman, and attended the inquest on his behalf. The inquest did not end in an acquittal, as Dr. Hicks states, but one of the assistants (Smytb), who admitted that he had reseived no medical education properly so termed - the man who had chief charge of the case-was censured by the cor $n+r$ 's jury; and it further transpired in the course of the inquest that he bad been previously censured by a coroner's jury while in the defendant's employment.

I should have thought it wonld have been more becoming on the part of Dr. Braxton Hicks to bave refrained from discussing the merits of a case in your columns in which he was concerned as a witness for the deferdant, and a barrister of the same name (bis son I believe) prof-ssionally concerned as junior connsel on behalf of the defendant at the bearing before the learned judye of the Whitechapel County Court.

I am, Sir, your faithful servant,

Clement J C. Pridham, Solicitor or 1 he Paaintuff in the action.

John-street, Bedford-row, W.C., June 266h, 1877. 